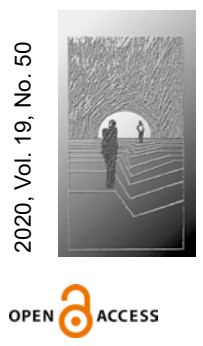

\title{
Potrzeba afirmacji człowieka jako wyzwanie dla wychowania
}

\section{STRESZCZENIE}

CEL NAUKOWY: Celem artykułu jest próba uzasadnienia tezy, zgodnie z którą współczesne wychowanie stanęło wobec szczególnego, pilnego wyzwania - mocnego oparcia się na antropologii afirmującej człowieka. Wymaga tego sytuacja z jednej strony wzmagającej się krytyki humanizmu, z drugiej - przedłużającej się pandemii koronawirusa.

PROBLEM I METODY BADAWCZE: Metodą badawczą jest analiza współczesnej sytuacji społeczno-kulturowej i pozycji w niej człowieka i człowieczeństwa w świetle personalistycznej myśli filozoficznej D. von Hildebranda, Ch. Delsol i R. Spaemanna.

PROCES WYWODU: Autorka wychodzi od charakterystyki obecnej sytuacji kultury dystansującej się coraz bardziej od idei humanizmu. Równocześnie zwraca uwagę na trudne konsekwencje wychowawcze sytuacji pandemii. Stawia tezę, że jedyną właściwą odpowiedzią jest afirmacja człowieka. Potrzebę takiej postawy uzasadnia, odwołując się do personalizmu chrześcijańskiego w ujęciu D. von Hildebranda, Ch. Delsol i R. Spaemanna. Wywód kończą wnioski dla wychowania.

WYNIKI ANALIZY NAUKOWEJ: Przeprowadzona analiza prowadzi do wniosku, iż jedynie personalizm chrześcijański pozwala w pełni uzasadnić potrzebę afirmacji człowieka, wyjaśnić jej rozumienie i wskazać sposoby realizacji tej postawy.

WNIOSKI, INNOWACJE, REKOMENDACJE: Wnioski przeprowadzonej analizy dotyczą możliwości kształcenia postawy afirmacji człowieka, wrażliwości na człowieczeństwo. Zdaniem autorki potrzebne jest kształcenie postaw wobec człowieka i świata warunkujących postawę afirmacji człowieka i świata - a to znaczy postaw uznania, zachwytu, podziwu, bezinteresowności.

\section{$\rightarrow$ SŁOWA KLUCZOWE: HUMANIZM, ANTROPOCENTRYZM, OSOBA, AFIRMACJA, BEZINTERESOWNOŚĆ}




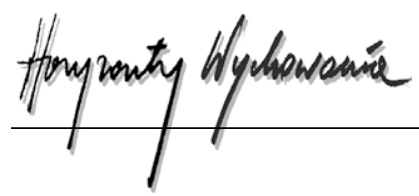

ABSTRACT

The Need for Affirmation of a Human as a Challenge for Upbringing

RESEARCH OBJECTIVE: The aim of the article is to attempt to justify the thesis that contemporary education has been facing a special, urgent challenge - a strong reliance on human-affirming anthropology. It is required by the situation, of the growing criticism of humanism on the one hand, and on the other - the prolonged coronavirus pandemic.

THE RESEARCH PROBLEM AND METHODS: The analysis of the contemporary socio-cultural situation and the position of man and humanity in it, in the light of the personalistic philosophical thought of D. von Hildebrand, Ch. Delsol and R. Spaemann.

THE PROCESS OF ARGUMENTATION: The author begins with a description of the current situation of culture that has been distancing itself gradually from the idea of humanism. At the same time, she draws attention to the difficult educational consequences of the pandemic situation. She argues that human affirmation is the only correct response. The author justifies a need for such an attitude by referring to Christian personalism as defined by D. von Hildebrand, Ch. Delsol and R. Spaemann. The argument ends with conclusions for upbringing.

RESEARCH RESULTS: The conducted analysis leads to the conclusion that only Christian personalism allows to fully justify the need of affirmation of a human being, to explain understanding of such a need, and to indicate ways of implementing this attitude.

CONCLUSIONS, INNOVATIONS, AND RECOMMENDATIONS: The conclusions of the conducted analysis concern the possibility of shaping the attitude of human affirmation and sensitivity to humanity. According to the author, it is necessary to create attitudes towards man and the world that condition the attitude of affirmation of man and the world - that is, the attitudes of recognition, awe, admiration and selflessness.

\section{$\rightarrow$ KEYWORDS: HUMANISM, ANTHROPOCENTRISM, PERSON, AFFIRMATION, SELFLESSNESS}

\section{Wstęp}

Koncepcja tych rozważań powstała jeszcze przed wybuchem pandemii koronawirusa, która tworząc ich dramatyczny kontekst, nadała im dodatkowy sens. Tocząca się na całym świecie walka z epidemią stała się walką o każde ludzkie życie. Ta ekstremalna sytuacja ujawniła różne wymiary człowieczeństwa. Ofiarność służb medycznych, rozwijające się inicjatywy pomocowe w różnej skali - środowiskowej, krajowej i międzynarodowej, powszechne zainteresowanie losem innych krajów zwiększyły wrażliwość na człowieczeństwo i jego wartość. Wzbudziły potrzebę okazywania uznania, podziwu, współczucia i wdzięczności. Równocześnie bardziej widoczne stały się egocentryzm 
i egoizm, kierowanie się własnym interesem, agresja spowodowana lękiem i frustracją, instrumentalizowanie innych (m.in. pracowników służby zdrowia - akceptowanych w aktywności zawodowej, ale już nie jako ludzi żyjących obok), mniej lub bardziej nieuczciwe wykorzystywanie tej sytuacji. Kolejny raz okazało się, że szczególnie w sytuacjach ekstremalnie trudnych potrzebne są zdecydowane postawy, przede wszystkim postawy wobec innych, a te nie rodzą się samorzutnie. Wymagają jasnej wizji człowieka, świata, sensu życia. Wspieranie ich kształtowania się i dojrzewania jest zasadniczym zadaniem wychowania.

Świat ogarnięty dziś pandemią nie jest jedynie światem dorosłych. Stał się światem wszystkich generacji, w tym dzieci, na których sytuacja wymusiła szybkie adaptowanie się do niezrozumiałych trudności. Jak zawsze młode pokolenie jest formowane przede wszystkim przez napotykane w otoczeniu wzorce zachowania i konkretne przykłady. Dziś dotyczą one zachowań związanych z przeżywaniem epidemii przez dorosłych, głównie przez osoby dla dzieci i młodych ludzi znaczące. To zachowania bliskich dorosłych wpłyną na to, czy dla dziecka drugi człowiek będzie kimś, z kim łączą go podobne trudności, kto wywołuje gotowość wzajemnej pomocy, czy też głównie zagrożeniem, nosicielem wirusa, konkurentem w walce o dostępne dobra. Można z dużym prawdopodobieństwem zakładać, że sposób patrzenia młodego człowieka na innych, jego stosunek do rzeczywistości, wrażliwość na potrzeby świata, cechy i postawy, kształtowane dziś przez środowisko, w którym żyje, wyznaczają i będą wyznaczać jego sposób życia nie tylko w tym traumatycznym czasie, ale i po wygaśnięciu epidemii.

Sposób formułowania problemów dotyczących zachowań i działań ludzkich, także wychowawczych, kierunki szukania rozwiązań, interpretacja wyników, wreszcie wnioski są (a przynajmniej powinny być) konsekwencją przyjmowanych założeń antropologicznych. Koncepcja człowieka wyznacza drogi analizy jego psychicznego i społecznego funkcjonowania, pozycję, jaką zajmuje w świecie, a w konsekwencji także zadania stawiane wychowaniu i wychowawcom. Globalna pandemia, która zaskoczyła świat XXI w., stała się nie tylko wyzwaniem cywilizacyjnym, ale także poważnym wyzwaniem moralnym. Coraz bardziej widoczne staje się, iż jej pokonywanie a potem radzenie sobie ze skutkami wymaga poczucia wspólnoty i odpowiedzialności za nią, empatii, wzajemnego zaufania, zrozumienia i solidarności, wrażliwego reagowania na trudne sytuacje innych, dostrzegania także potrzeb świata. Wymuszona sytuacją epidemii, przedłużająca się konieczność dystansu społecznego w codziennych kontaktach może wywierać znaczący wpływ na stosunki między ludźmi. Jak stwierdza psychologia, dystans społeczny, odosobnienie tłumią empatię, w wyniku czego słabnie altruizm (Goleman, 2007, s. 80-81). Dostrzeganie potrzeb innych i odpowiednie na nie reagowanie będzie więc wymagało niezależnego od dystansu pozytywnego nastawienia, traktowania każdego człowieka jak wartości samej w sobie.

Patrzenie na świat i człowieka musi się zmienić z dominującego dziś patrzenia pragmatycznego, nieufnego, podejrzliwego, na widzenie w człowieku i w świecie najważniejszych, niezastępowalnych wartości, wartości samych w sobie. Taką koncepcją człowieczeństwa jest personalizm - myślenie o człowieku jako osobie. Podstawą dalszych 


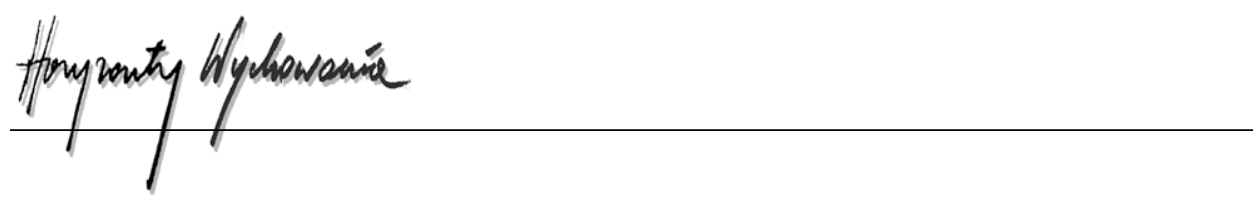

rozważań będzie personalizm o źródłach chrześcijańskich, który uzasadnia ludzką godność, fizyczno-psychiczno-duchową integralność i wyjątkowość. To na gruncie tej koncepcji będziemy się starali uzasadnić potrzebę afirmacji człowieka i świata, zwiększenia świadomości ich bezwarunkowej wartości, potrzebę uwzględnienia takich założeń w wychowaniu i samowychowaniu.

\section{Obrona humanizmu czy człowieczeństwa?}

W dzisiejszej kulturze można obserwować narastającą nieufność i niechęć wobec humanizmu, jego coraz ostrzejszą krytykę. Wcześniejsze obawy o człowieka, o dehumanizację świata zdominowanego przez technicyzację, świata zmaterializowanego, traktującego człowieka przedmiotowo, zastąpiło dziś zwątpienie w człowieka. Zjawisko to nasila się jako reakcja na powszechną akceptację postaw utylitarnych i konsumpcyjnych, które sprawiają, że dla własnej korzyści (jako szeroko rozumianej przyjemności i zysku) człowiek jest gotowy wykorzystywać instrumentalnie nie tylko przyrodę, nie tylko innych ludzi, ale nawet siebie. Powszechne przyjmowanie takich postaw wywołuje coraz ostrzejszą ich krytykę, coraz większą determinację w poszukiwaniu nowego sposobu rozumienia humanizmu, nowego podejścia do człowieczeństwa. Często stanowiska reprezentujące ten nurt myślenia podważają najwyższy status człowieka, odnosząc się krytycznie do tradycyjnej idei humanizmu. Uznają, że jej przyjmowanie niejako upoważnia człowieka do zawłaszczania świata, bez zwracania uwagi na odpowiedzialność za innych ludzi i naturę. Trzeba jednak zauważyć, że redukują one człowieka do istoty biologicznej lub społecznej. Konsekwencją takiego myślenia są hasła posthumanizmu, który nieprzypadkowo postuluje zerwanie z podziałem na kulturę i naturę, proponując pojęcie „kulturonatury”.

W innych ujęciach, również dostrzegających niebezpieczeństwa nowożytnego humanizmu, akcentuje się potrzebę sformułowania tej idei i programu niejako na nowo. Szczególne miejsce zajmuje tu personalizm o korzeniach chrześcijańskich, jako humanizm uznający w człowieku osobę - istotę o wyjątkowym, najwyższym statusie, jedyną w świecie obdarzoną bezwarunkową godnością, istotę rozumną i wolną.

Kiedy francuska filozof Chantal Delsol publikowała w ostatnich latach swoje książki (Delsol, 2003; 2011; 2018) zawierające alarmistyczną diagnozę współczesnej kultury, szczególnie dehumanizującej się kultury Zachodu, nikt nie przypuszczał, że odczytywane w 2020 r. nabiorą nowego znaczenia.

Ich zasadniczym przesłaniem była potrzeba, a nawet konieczność powrotu do konstruktywnej antropologii, do fundamentalnej dla kultury Zachodu koncepcji człowieka jako osoby. Delsol analizuje coraz bardziej widoczne współcześnie słabnięcie personalizmu, zanik rozumienia jego założeń (w tym - uzasadnienia godności), a tym samym błędne interpretowanie statusu osoby ludzkiej. Jej zdaniem atakowanie tej antropologii to skutek rozczarowania człowiekiem i człowieczeństwem widzianym przez pryzmat tradycyjnego humanizmu i nowożytnej filozofii podmiotu. Humanizm jest w tych stanowiskach 
kojarzony z agresywnym antropocentryzmem. W tak rozumianym humanizmie człowiek, któremu przyznano najwyższą pozycję, resztę świata traktuje jak pole swojej bezwzględnej ekspansji. Filozofka ta pisze:

Radykalizacja antropocentryzmu zrodziła człowieka-pana i władcę przyrody, którego potęga okazuje się nieakceptowana pod żadnym względem, bo swoją władzę sprawuje on bezrefleksyjnie i nieodpowiedzialnie, a ostatecznie zabija wszystko, czego tknie (Delsol, 2018, s. 83-84).

Postulowany przez nią powrót do personalizmu wynika z przekonania, że idea człowieka jako osoby jest i będzie wciąż nowa.

Pojęcie osoby ma długą historię i na jej przestrzeni przyjmowało różne znaczenia. W kulturze chrześcijańskiej, która wywarła poważny wpływ na powstanie i ostateczny kształt kultury zachodniej (a także na powstałą na jej gruncie Powszechną deklarację praw człowieka), traktowanie człowieka jako osoby jest uzasadniane filozoficznie i religijnie.

U podstaw uzasadnienia godności człowieka leży uznanie jego transcendencji, tego iż jest istotą stworzoną przez Boga, jest Jego obrazem, dzieckiem Bożym, istotą zobowiązaną do odpowiedzialności za stworzony i powierzony jej przez Boga świat.

W jednej z ostatnich książek Delsol czytamy:

Chrześcijaństwo to jedyna koncepcja pozwalająca połączyć filozofię podmiotu z poszanowaniem naturalnego porządku. Człowiek nie stapia się tu z naturą, co pozwala mu być podmiotem, ale też nad nią nie panuje, będąc tylko ogrodnikiem (...). Ogrodnik, dzierżawca muszą okazywać szacunek (Delsol, 2018, s. 117).

Wybitny współczesny filozof niemiecki Robert Spaemann, do którego będziemy się szerzej odwoływać w dalszej części, napisał:

Teoretycznego uzasadnienia idei godności człowieka i jej nienaruszalności dostarcza jednak tylko metafizyczna ontologia, tj. filozofia tego, co absolutne. Dlatego ateizm definitywnie pozbawia ideę godności człowieka jej uzasadnienia, a tym samym możliwości teoretycznego ostania się w danej cywilizacji (Spaemann, 2006, s. 168).

A w innym miejscu:

To, co dzisiaj nazywamy osobą, bez teologii chrześcijańskiej pozostałoby nie nazwane, a ponieważ osoby nie są po prostu zdarzeniami naturalnymi, byłoby w świecie nieobecne (Spaemann, 2001, s. 25).

Człowiek jako osoba (ktoś, a nie coś) posiada bezwarunkową godność. Wyposażony w rozumność i wolność spełnia się w relacjach osobowych - relacjach z innymi, we wspólnotach - naturalnych (przede wszystkim w rodzinie), ale też wybieranych i tworzonych. Relacje te opierają się na szacunku i miłości. Afirmacja jest niejako splotem, zespoleniem 


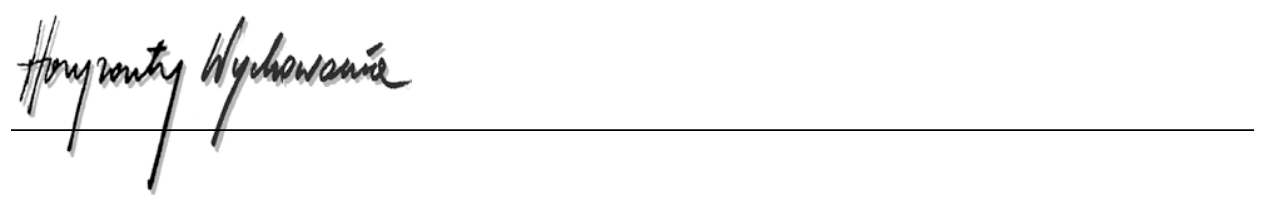

tych dwu postaw. Wyraża się nie tylko bezinteresowną potrzebą poznawania, gotowością odkrywania wartości wyższych (prawdy, dobra i piękna) i ich urzeczywistniania, ale podziwem i zachwytem. Nie chodzi tu o postawę łączącą się z optymizmem, zadowoleniem i szczęściem - jak interpretuje się ją często w dyskursie społecznym. Mowa tu o afirmacji rozumianej jako bezwarunkowe uznanie czegoś za dobre, głęboka akceptacja, podkreślanie wartości, pozytywny stosunek mimo trudności i rozczarowań. Tak rozumiana afirmacja zakłada bezinteresowność w podejściu do afirmowanego przedmiotu - człowieka, zjawiska, świata. Tym samym postawa ta jest w znacznym stopniu uwarunkowana zdolnością i gotowością do przyjmowania postawy bezinteresowności wobec prawdy, dobra i piękna w człowieku i w świecie.

Warto w tym miejscu przywołać niemieckiego filozofa i teologa Dietricha von Hildebranda. Podkreślając fundamentalne znaczenie, jakie w byciu i działaniu osobowym, w wielorakich relacjach ze światem wartości ${ }^{1}$ ma życie moralne, za najważniejszą postawę moralną uważa on postawę prawości, obejmującą afirmację człowieka i świata. Postawa ta umożliwia odkrywanie wartości dobra i piękna, rozwój pozostałych postaw moralnych (wierności, odpowiedzialności, poszanowania prawdy, dobroci) jest warunkiem każdej prawdziwej miłości. O człowieku prawym Hildebrand pisze:

Jest pozbawiony egoizmu, pychy i pożądliwości. Nie wypełnia świata swoim własnym „ja”, lecz wszystkim i wszystkiemu daje możność rozwijania swoich przymiotów i właściwości. Rozumie godność i szlachetność tego, co istnieje, wartość, którą to posiada jako coś istniejącegow przeciwieństwie do nicości. Rozumie wartość, którą reprezentuje każdy kamień, kropla wody, każde źdźbło trawy jako rzecz istniejąca, jako twór posiadający swoje własne jestestwo (...). Toteż nie uważa istniejącej rzeczywistości jedynie za środek do osiągnięcia własnych, przypadkowych, egoistycznych celów i zamiarów ani za coś, co może spożytkować lub użyć, lecz wychodzi ku tej rzeczywistości traktując ja poważnie dla niej samej, dając jej szanse pełnego rozwoju (...) wie, że nie jest panem i władcą, który może według swego widzimisię rządzić tym co istnieje, lecz powinien się od tego wszystkiego uczyć (Hildebrand, Kłoczowski, Paściak i Tischner, 1982, s. 15-16).

\section{I dalej:}

postawa prawości jest fundamentem wszelkiego etycznego odnoszenia się do ludzi i do siebie samego. Tylko przed człowiekiem prawym może się otworzyć cała wielkość i głębia wartości, która tkwi w każdym człowieku jako osobie (Hildebrand, Kłoczowski, Paściak i Tischner, 1982, s. 17).

Jest to więc zadanie dla współczesnego wychowania: szukać dróg wychowywania do bezinteresowności i afirmacji. Inspiracją może być filozofia Roberta Spaemanna.

${ }^{1}$ D. von Hildebrand rozróżnia dobra subiektywnie zadowalające, obiektywnie dobre dla człowieka i wartości same w sobie. Tylko te ostatnie uważa za wartości. 


\section{Afirmacja człowieka i świata - w świetle filozofii Roberta Spaemanna}

Wśród reprezentantów myśli personalistycznej zaznaczają się dwa zasadnicze podejścia. Jedno, które przyjmując substancjalną pierwotność osoby, uznaje iż z samego bycia człowiekiem wynika bycie osobą - istotą nieredukowalną do żadnego zespołu cech, właściwości czy jakości, oraz drugie, które neguje substancjalność i bezwarunkowość osoby, uzależniając jej status od różnych kryteriów. Wspomniany wyżej Robert Speamann rozumie osobę substancjalnie. W jego filozofii można odnaleźć wątki, które wydają się szczególnie inspirujące dla refleksji o wychowaniu. Pierwszy dotyczy istoty relacji osobowych, drugi - stosunku do świata, do rzeczywistości, w której człowiek żyje. Obydwa łączą się w akcentowaniu potrzeby afirmacji człowieka i świata. Oprócz wychowawczych konsekwencji prezentowanego przez Spaemanna sposobu myślenia o człowieku jako osobie warte przywołania są również jego poglądy odnoszące się bezpośrednio do wychowania, do jego funkcji, a także zadań adresowanych do osób wychowujących.

O pojęciu osoby Speamann pisał: „Stosując pojęcie osoby do jednostek, przyznajemy im określony status, status nietykalności. Wraz z przyznaniem tego statusu przyjmujemy zobowiązanie do uznania jego ważności” (Spaemannn, 2001, s. 24). Bycie osobą „nie jest cechą gatunkową, lecz statusem, i to jedynym statusem, który nie został nikomu nadany przez innych, lecz każdemu przysługuje z natury" (Spaemannn, 2001, s. 24).

Uznanie ważności wymaga, zdaniem autora, bezinteresownego szacunku.

Uznanie kogoś za osobę oznacza najpierw ograniczenie swej własnej, zasadniczo nieograniczonej tendencji do ekspansji, rezygnację z widzenia innego tylko w aspekcie znaczenia, jakie ma w moim kontekście życia, szacunek dla niego jako ośrodka własnego kontekstu znaczeń, który nigdy nie jest mi dany przedmiotowo (Spaemannn, 2001, s. 228).

Jeszcze wyraźniej bezinteresowność ta jest widoczna w rozumianej osobowo miłości.

Sposób, w jaki samoistne bycie każdego człowieka wnosi roszczenie do bycia rzeczywistym dla każdego innego, to uznanie. Aby być zdolnym do uznania każdego innego, trzeba prawdopodobnie chociaż raz bezpośrednio doświadczyć samoistnego bytu kogoś innego, to znaczy kochać i być kochanym. Reszta to wierność (Spaemannn, 2001, s. 96).

Rozwinięcie tej myśli znajdujemy w wielu fragmentach rozważań o osobie.

Elementarnym poziomem relacji osób jest uznanie, poziomem w sensie osobowym najwyższym - miłość. Miłość jest tą egzystencjalną samotranscendencją, w której duch i dusza, uniwersalność i przeżycie stają się jednym. (...) Ze swej istoty miłość nie ma końca. Absolutna afirmacja innego - jeśli odpowiada swemu pojęciu - nie może się skończyć (Spaemannn, 2001, s. 199). 


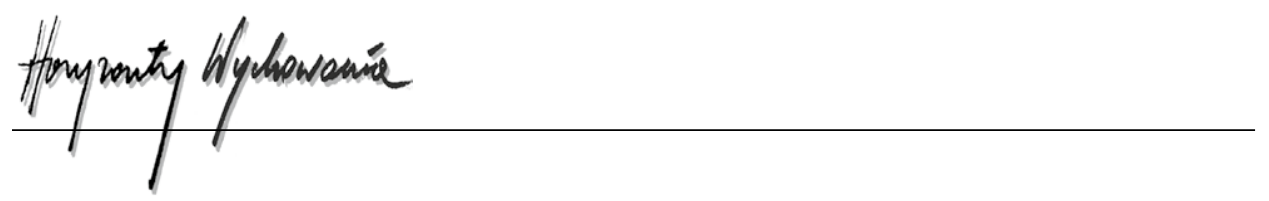

W innym miejscu Spaemann powie o niezbędnej w miłości afirmacji kochanej osoby:

Kiedy kogoś kochamy, ów ktoś, to określone, jedyne i niepowtarzalne życie, stało się dla nas rzeczywiste, a tym samym stało się przedmiotem bezwarunkowej afirmacji jego egzystencji (Spaemann, 2006, s. 146).

Zastanawiając się nad tym, jaki czyn można nazwać „dobrym”, autor kolejny raz podkreśli znaczenie postawy afirmacji. Pisze:

Ostatecznie to nie czyny są dobre, lecz ludzie. A to, co czyni ludzi dobrymi, w tradycji chrześcijańskiej nosi miano „miłości”. Jest to postawa zasadniczej afirmacji rzeczywistości. Wypływa z niej uniwersalna życzliwość, w świetle której my sami nie jesteśmy już centrum świata, choć rozciąga się ona również na nas: aby żyć dobrze, trzeba żyć w przyjaźni również z samym sobą (Spaemann, 2000, s. 82).

Można więc przyjąć, że afirmacja oznacza tu postawę bezinteresownego uznania, rezygnującego z egoistycznie rozumianych korzyści osobistych (szukania we wszystkim własnego „interesu”, w tym - własnej przyjemności), łączącego się z miłością. Rezygnacja z koncentracji na sobie, bezinteresowne uznanie godności drugiego, pozostawienie mu wolności jest warunkiem szacunku i miłości, a te są podstawą relacji osobowych. „Pozytywnie rezygnacja ta oznacza: pozwolić być, «pozwolić być» to akt transcendencji, który jest właściwą oznaką bycia osobą” (Spaemann, 2001, s. 96). „Pozwolić być” oznacza równoczesne uznanie przysługującej każdemu niepowtarzalnej, związanej jedynie z nim przestrzeni we wspólnotach (w pierwszym rzędzie naturalnych - rodzinie, narodzie, ludzkości) i w świecie. Spaemann wyjaśnia to następująco:

Osób nie można, tak jak istot pozaludzkich, traktować jako gałęzi tego samego drzewa, lecz należy je traktować jako abstrakcyjne miejsca w fizykalnej przestrzeni. I tak jak te miejsca, są one zawsze rzeczywiste (Spaemann, 2001, s. 87).

W innym miejscu możemy przeczytać:

Bycie osobą jest zajęciem miejsca nie istniejącego bez przestrzeni, w której również inne osoby mają swoje miejsce. Zajęcie tego miejsca nie polega na przydzieleniu go nam przez tych, którzy byli tu już przed nami. Każdy człowiek zajmuje to miejsce na mocy własnego prawa, jako członek z urodzenia Ale nie spotyka się go na tym miejscu na sposób empiryczny, lecz przestrzeń tę postrzega się tylko na sposób uznania (Spaemann, 2001, s. 222-223).

Jedyność i niepowtarzalność miejsca każdej osoby w świecie prowadzi do głębszego zrozumienia istoty relacji we wspólnocie osobowej (szczególnie w rodzinie). Cytowany autor stwierdza:

Osoby nie są „dodawalne”. Ustanawiają one między sobą system relacji, w którym każda osoba ma własne miejsce w relacji do wszystkich innych osób. (...) Jeśli jednak „osoba” oznacza kogoś zajmującego niepowtarzalne miejsce w ukonstytuowanej przez osoby przestrzeni, to siebie i innych postrzegamy jako zajmujących takie miejsce uno actu. 
Postrzegać ludzi jako osoby oznacza postrzegać aprioryczną przestrzeń relacji, którą osoby konstytuują. I tylko wraz z tą przestrzenią odkrywamy siebie jako osoby (Spaemann, 2001, s. 226).

Taki sposób myślenia pozwala niejako na nowo spojrzeć na wymóg respektu dla przysługującego każdemu człowiekowi szacunku. Pomaga zrozumieć, że w praktyce respekt ten powinien się przejawiać uznaniem niepowtarzalności, wyjątkowości każdego, troską o to, by znalazł w świecie swoje miejsce, własną życiową przestrzeń, w której będzie rozwijał własne człowieczeństwo. Miejsce to nie ma być jednak obszarem zamykającym człowieka w jego indywidualności, osobistych potrzebach, dystansowaniu się do innych. Ma budować relacje osobowe, które stwarzają warunki dla sprawiedliwego, ale i opartego na miłości rozwoju każdej ze stron, uznawanej w całej swojej godności.

Obserwowany dziś coraz częściej brak szacunku do człowieka, traktowanie go instrumentalne, przedmiotowe, jak anonimowego elementu różnych zbiorowości, przekłada się na kształt życia społecznego, na coraz poważniejsze problemy i konflikty zarówno jednostkowe, jak społeczne, w tym - co szczególnie ważne dla wychowania - na sytuację w rodzinach. Sytuację tę, jak w każdej wspólnocie osób, budują głównie wzajemne relacje członków rodziny. Współcześnie relacje te coraz wyraźniej zatracają wymiar osobowy. Coraz rzadziej opierają się na szacunku, miłości, wzajemnym uznawaniu swojej niepowtarzalności, na pozostawianiu sobie wzajemnie przestrzeni wolności. Dzisiejsza praktyka życia rodzinnego ujawnia raczej podejścia, które nakładając się na siebie, niszczą osobowy charakter rodziny, uniemożliwiają jej bycie osobową wspólnotą. Z jednej strony jest to podkreślanie i obrona prawa do indywidualnego rozwoju każdego z jej członków, do wykorzystywania przez nich własnego potencjału. Wynikające z takiego myślenia pozostawianie każdemu jak największej wolności często oznacza jednak w praktyce brak zainteresowania, wzajemnej uważności, gotowości wspierania w sytuacjach trudnych. Z drugiej - nierzadko dochodzi do zawłaszczania innych, traktowania ich jak własności, oceniania głównie ze względu na zakładane walory i oczekiwane profity (materialne i psychiczne). Może to doprowadzić do całkowitego podporządkowania słabszych - mocniejszym (nawet poprzez przemoc fizyczną czy psychiczną).

Uznanie w każdym człowieku osoby ze względu na przysługującą mu bezwarunkową godność oznacza, jak zaznaczono wcześniej, jego afirmowanie. Ta postawa wiąże się z afirmowaniem świata, w którym człowiek żyje. Według Spaemanna (na co zwraca uwagę analizujący jego poglądy na wychowanie Józef Kożuchowski) „z natury człowiek jest jednak zdolny dostrzegać piękno życia i zachwycać się nim, niezależnie od tego, jaki los go spotkał". Zachwyt ten wiąże się z bezinteresowną chęcią poznania świata, która motywuje do skupienia i koncentracji uwagi. Dlatego w świetle poglądów Spaemanna zdolność odkrywania najważniejszych wartości - prawdy, dobra i piękna - wymaga uczenia bezinteresownej koncentracji uwagi „pozbawionej pragmatyzmu” (Kożuchowski, 2016, s. 29-30). W dzieciach i młodych ludziach należałoby więc budzić i pielęgnować zdolność do afirmacji - do zachwytu i podziwu nad istniejącym światem, a w przypadku osób wierzących - nad światem stworzonym przez Boga. 


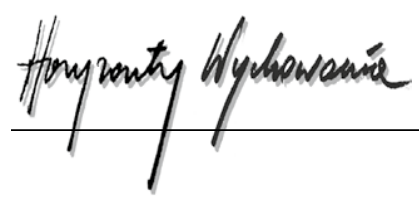

Z potrzebą afirmacji człowieka i świata wiąże się ważny wątek wychowawczego wymiaru relacji między ludźmi. Zdaniem Spaemanna, w świetle myślenia osobowego już samo współbycie osób staje się wychowaniem, nawet jeśli nie uczestniczą w nim dorośli w roli wychowawców. Ci ostatni mają w wychowaniu specjalne zadania, za które powinni się czuć odpowiedzialni. Najważniejsze z nich to podtrzymywanie pamięci i odsłanianie przeszłości. To zadanie powinni przyjąć na siebie w głównej mierze dorośli członkowie rodziny. To oni powinni dbać o przenoszenie między pokoleniami ważnego doświadczenia. Doświadczenie to jest bowiem podstawą tożsamości indywidualnej i zbiorowej, płaszczyzną porozumienia we wspólnotach osobowych, przede wszystkim naturalnych (odpowiednio do ich zasięgu - w rodzinie, narodzie, ludzkości), fundamentem budowania przyszłości. Szczególną rolę w życiu człowieka odgrywa pamięć dzieciństwa, która, jeśli zachowuje przede wszystkim pozytywne obrazy, daje siłę, motywację i nadzieję na poradzenie sobie w życiu. Dlatego warte podkreślenia jest przekonanie Spaemanna, że dorośli są odpowiedzialni za pozytywną pamięć dzieciństwa swoich wychowanków. Pozbawianie dzieci radości życia, deformowanie im obrazu świata przez podkreślanie dominacji zła i cierpienia jest z tej perspektywy antywychowawcze (Kożuchowski, 2016, s. 28).

Interesujące są wnioski Spaemanna dotyczące bezpośrednio wychowania. Pokazują, jakie myślenie wynika z afirmowania człowieka i świata, zarówno tego, w którym się żyje, jak i tego, który jest nieznaną przyszłością. Jego zdaniem wyrazem szacunku do młodego pokolenia jako pokolenia wychowanków jest uznanie, iż będą oni żyli w rzeczywistości, którą sami dopiero będą budowali i która nie jest na tyle przewidywalna, żeby można do niej właściwie czy odpowiednio się „przygotować”. To uznanie powinno jednak zobowiązywać do przekazywania między generacjami doświadczenia osób i wspólnot, do odsłaniania kolejnym pokoleniom przeszłości, na której będą mogły budować przyszłość.

Ważne z perspektywy wychowania sfery, jakie - w świetle Spaemanna filozofii osoby wymagają specjalnej troski, zaangażowania, rozwijania, by ludzie mogli wzrastać w osobowym człowieczeństwie, to: bezinteresowna afirmacja świata, w nim - każdego człowieka, a także budowanie relacji opartych na uznawaniu jego bezwarunkowej godności, na jego afirmacji. Oznacza to obdarzanie go szacunkiem i miłością, pozostawianie mu w relacjach i życiu wspólnotowym przestrzeni respektującej jego wolność, niepowtarzalność i jedyność.

\section{Refleksje końcowe}

Pozostając w nurcie myślenia Spaemanna, trudne byłoby wskazywanie konkretnych rozwiązań wychowawczych, które służyłyby wprowadzaniu młodego pokolenia w afirmowanie człowieka i świata, uczyły bezinteresowności, będącej niezbędnym elementem podziwu i zachwytu, bez której nie można mówić o szacunku i miłości. Decydujące jest takie współbycie z wychowankami, które wprowadza ich w doświadczenie szacunku dla niepowtarzalności i wartości każdego człowieka, zachwytu i podziwu nad nim i światem. Dlatego tak ważne jest wyrażanie w obecności dzieci, i do nich, swojego zachwytu, 
podziwu, zdumienia, radości, wzruszenia, uczenie ich uważnego obserwowania świata natury (roślin, zwierząt, krajobrazów itp.) i ludzi nie ze względu na oczekiwane profity, ale na ważność i piękno tego, co się obserwuje. Stopniowo aktywność ta może się rozwinąć w kontemplację tych wartości. Osobiste doświadczenie powinno być wspierane podobnymi doświadczeniami innych, poznawanymi i przeżywanymi przez kontakt z różnymi dziedzinami sztuki, przez poszukiwania i odkrycia naukowe (wielu uczonych zwraca uwagę na piękno odkrywane przez nich w poznawanym świecie), przez opowieści i rozmowy. Ogromną rolę odgrywa tu literatura dla dzieci. W swoich najwybitniejszych utworach zakłada ona refleksyjny odbiór także przez dorosłych, ucząc ich wrażliwego, bardziej bezinteresownego (w dziecięcy sposób), nie jedynie pragmatycznego patrzenia na ludzi i świat, sposobu wprowadzania dzieci w takie właśnie patrzenie, stwarzając okazje do wspólnego przeżywania i dzielenia się myślami i uczuciami.

Coraz ważniejszym zadaniem staje się w tym kontekście kształcenie od najmłodszych lat postawy bezinteresowności. Najbardziej właściwą drogą jest stwarzanie sytuacji wymagających rezygnacji z egocentryzmu i egoizmu na rzecz konkretnego działania z innymi i dla innych, troski o świat w różnych jego wymiarach (przyrody, klimatu, dóbr naturalnych, krajobrazu), dobra wspólnego pozwalającego na zapewnianie możliwie każdemu człowiekowi warunków do osobowego bycia i rozwoju. Jest to droga przez drobne okazje stwarzane w domu aż do wspólnego podejmowania różnych form wolontariatu.

Oczywiście, jak w każdym działaniu pedagogicznym, nie można pomijać sfery kształcenia intelektu - stopniowego wprowadzania w wiedzę o człowieku jako osobie, potrzebach świata i ludzi, o prawdzie, dobru i pięknie oraz innych wartościach. Także tu potrzebne jest kształcenie uważności, skupienia, rezygnacji z pośpiechu. Procesy te muszą być dostosowane do możliwości uczestników, tzn. wszystkich, którzy ucząc się (w różnych rolach: uczniów, nauczycieli, pomocników i współpracowników), wzajemnie wzbogacają swoje poznawanie, motywują się wzajemnie zainteresowaniem, zdumieniem, zachwytem, podziwem, poświęcanym czasem. Wspólne poznawanie łączy się ze wspólnym myśleniem o najważniejszych wartościach, ich odkrywaniem, przeżywaniem i realizowaniem.

Dla refleksji o wychowaniu i samowychowaniu, ale i dla praktyki wychowawczej dyskusje o statusie, tożsamości, istocie człowieka i człowieczeństwa mają zasadnicze znaczenie. Pytania o przyszłość, w której idea humanizmu zostanie zastąpiona przez transhumanizm bądź posthumanizm a wizja człowieka - przez wizję postczłowieka, o łączenie wrażliwości ekologicznej nie z myśleniem humanistycznym, ale „posthumanistycznym”, pytania stawiane przez intelektualistów i publicystów, uczonych i artystów nie mogą być obojętne dla pedagogów. Przyjmowane przez współczesną kulturę poglądy na miejsce i rolę człowieka w świecie, na kryteria określania człowieczeństwa wobec rosnących możliwości manipulacji genetycznych i oczekiwań wobec sztucznej inteligencji zadecydują o sensie i roli nadawanym wychowaniu. Zadecydują o przyszłości tej sfery zachowań społecznych, o przyjmowanych celach i formach działania wychowawczego, jego zakresie i prawomocności. 


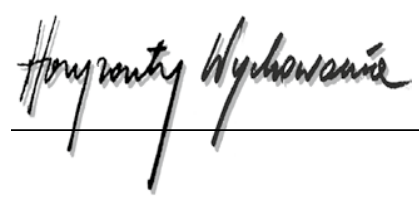

Konkluzją tych rozważań jest uznanie, że wobec rosnącego zwątpienia w człowieka, widzenia w nim istoty zagrażającej światu, potrzebne jest podkreślanie wyjątkowości i wartości człowieczeństwa. Nie człowieczeństwa interpretowanego jedynie biologicznie, czy społecznie, ale osobowo, człowieczeństwa opartego na bezwarunkowej godności, wiążącego się równocześnie z odpowiedzialnością za innych ludzi, za siebie i świat, z życiem moralnym wyznaczającym postępowanie we wszystkich dziedzinach. Coraz częstsze przeciwstawianie człowieka i świata kultury jako rozwijania człowieczeństwa, światu natury, podważa sens wychowania. Jego istotą jest bowiem wspieranie ludzi w tym rozwoju. Równocześnie zamazuje potrzebę samowychowania. W tym kontekście coraz pilniejszym wyzwaniem dla kultury, w tym - dla wychowania - jest zmiana perspektywy: z wątpienia w człowieka - w jego afirmowanie jako osoby i świata, w którym żyje. Potrzebne jest wychowanie, które kształtowałoby takie postawy.

$\mathrm{Na}$ jednej z ilustracji pięknej książki dla dzieci Charliego Mackesy’ego o tym, co w życiu jest ważne, jej bohaterowie - przyjaciele chłopiec, kret i lis, siedzą, wpatrując się w nocne niebo. Podpis wyraża ich myśli: „jest tyle piękna, o które musimy się troszczyć”.

\section{BIBLIOGRAFIA}

Delsol, Ch. (2003). Esej o człowieku późnej nowoczesności. Przekł. M. Kowalska. Kraków: Wydawnictwo Znak.

Delsol, Ch. (2011). Czym jest człowiek? Kurs antropologii dla niewtajemniczonych. Przekł. M. Kowalska. Kraków: Wydawnictwo Znak.

Delsol, Ch. (2018). Kamienie węgielne. Na czym nam zależy? Przekł. M. Kowalska, Kraków: Wydawnictwo Znak.

Goleman, D. (2007). Inteligencja społeczna. Przekł. A. Jankowski. Poznań: Dom Wydawniczy Rebis.

Hildebrand, D. von, Kłoczowski, A.J., Paściak, J. i Tischner, J. (1982). Wobec wartości. Poznań: „W drodze”, 7-51

Kożuchowski, J., (2016). Wychowanie jest aktem odwagi. Wizja Roberta Spaemanna. Wychowanie w Rodzinie, t. XIII, 1, 19-37

Mackesy, Ch., (2020), Chłopiec, kret, lis i koń. Przekł. M. Słysz. Warszawa: Wydawnictwo Albatros Sp. z o.o.

Spaemann, R. (2000). Podstawowe pojęcia moralne. Przekł. P. Mikulska i J. Merecki. Lublin: Redakcja Wydawnictw Katolickiego Uniwersytetu Lubelskiego.

Spaemann, R. (2001). Osoby. O różnicy między czymś a kimś. Przekł. J. Merecki. Warszawa: Oficyna Naukowa.

Spaemann, R. (2006). Granice. O etycznym wymiarze działania. Przekł. J. Merecki. Warszawa: Oficyna Naukowa.

\section{Copyright and License}

This article is published under the terms of the Creative Commons Attribution - NoDerivs (CC BY- ND 4.0) License http://creativecommons.org/licenses/by-nd/4.0/ 